\title{
BACTERIAL LOAD IN RELATION TO PHYSICO-CHEMICAL PARAMETERS AND FAECAL INDICATORS OF DRINKING WATER SOURCE
}

\author{
SLAVICA ĆIRIĆ ${ }^{*}$ ， DANIJELA PRODANOVIĆ ${ }^{1}$, BOŽIDAR MILOŠEVIĆ ${ }^{1}$, MARIJA \\ PRODANOVIĆ ${ }^{1}$
}

${ }^{1}$ Faculty of Agriculture, University of Priština, Lešak, Serbia

\begin{abstract}
The aim of this study was to examine the relationship between bacterioplankton and physico-chemical parameters of water that serves as a source of drinking water as well as the relationship between bacterioplankton and the indicators of faecal contamination of water. Bacterioplankton abundance was determined by the cultivation method which included the inoculation of water samples on PCA and R2A media and incubation at $20{ }^{\circ} \mathrm{C}$ for 7 days. Total bacterial count was determined by epifluorescence microscopy, and three bacterial morphotypes were distinguished: rods, cocci and curved forms. Bacterial biomass was also determined. Eleven physico-chemical parameters of water were determined: temperature, $\mathrm{pH}$, turbidity, conductivity, $\mathrm{UV}$ extinction, $\mathrm{KMnO}_{4}$ consumption, total phosphorus, orthophosphates, ammonium-, nitrite- and nitrate nitrogen. As indicators of faecal contamination, the counts of total coliforms, faecal coliforms, faecal streptococci and sulphite-reducing clostridia were determined. Although there were significantly higher number of bacteria on R2A medium in relation to PCA medium, both media showed significant negative correlation of aerobic mesophilic bacteria with water temperature, in all seasons, and significant positive correlation with UV extinction, turbidity, $\mathrm{KMnO}_{4}$ consumption, total phosphorus, orthophosphates, ammonium nitrogen and nitrate nitrogen. Also, these bacteria showed significant positive correlation with total bacterial count and bacterial biomass, as well as bacterial indicators of faecal contamination.
\end{abstract}

Keywords: Drinking water, Physico-chemical parameters, Aerobic mesophilic bacteria, Faecal indicators.

\section{INTRODUCTION}

The primary point in water supply is the source of drinking water. The quality of the water source is the basic guidance for the selection of processing technology, and the change in this quality is one of the main causes of the deterioration of the quality of water that reaching consumers. In order to respond in a timely manner, in terms of preventing the potential negative impacts of water of inadequate quality on consumers' health, constant monitoring of the basic indicators of the water source status is necessary. The quality of water is defined in terms of its physical, chemical and biological (bacteriological) parameters, and ascertaining its quality is important before use for various intended purposes such as potable, agricultural, recreational and industrial water usages, etc. (Sargaonkar \& Deshpande, 2003).

The bacteriological quality of water has traditionally been assessed by monitoring the counts of total coliforms, faecal coliforms and faecal streptococci. Sulphite-reducing clostridia (such as Clostridium perfringens) has been suggested as an alternative bacterial indicator of faecal pollution because it is consistently associated with human wastes (Bezirtzoglou et al., 1997).

\footnotetext{
* Corresponding author: slavica.ciric@mts.rs BIOLOGY
}

Bacteria comprise a significant part of planktonic biomass and are responsible for contributing productivity and nutrient cycling in aquatic systems (Muylaert et al., 2002). They have fast growth rates and respond to low levels of pollutants as well as other physical, chemical and biological environmental changes. From detection and effect perspectives, they provide sensitive, meaningful and quantifiable indications of ecological change (Paerl et al, 2003; Freese et al., 2006). Particularly in polluted waters rich in nutrients, bacterial biomass and production are high (Chróst \& Siuda, 2006) and heterotrophic bacteria numerically dominate in the bacterioplankton (SzelągWasielewska \& Stachnik, 2010). The parameter "heterotrophic bacteria", in our country is called "aerobic mesophilic bacteria", which is more appropriate, because the term "heterotrophic bacteria" refers to all bacteria requiring organic matter for their growth, while all cultivation methods for determining the total count of bacteria detect only a part or subpopulation of heterotrophic bacteria in water or another environment. The monitoring of water supplies for the count of aerobic mesophilic bacteria is useful for monitoring trends or detecting sudden changes in water quality (EA UK, 2002).

According to WHO (2002), heterotrophic plate counts alone cannot indicate a health risk and additional studies on the presence of $E$. coli or other faecal specific indicator microorganisms need to be conducted to establish the potential health risk of the analysed water. Aerobic mesophilic bacteria are 
not indicators of potential risk for human health but some of them are opportunists and can cause various human infections (Bertram et al., 2003). In recent years, a great attention has been paid to non-faecal opportunistic pathogens (Proctor \& Hammes, 2015), which mainly belong to the population of aerobic mesophilic bacteria.

Some studies emphasized that appearance and growth of microbiological populations in water can be associated with elevated values of some physico-chemical parameters (Liguori et al., 2010; Poma et al., 2012).

The purpose of this study was to define physico-chemical and bacteriological characteristics of Ćelije Reservoir and the raw water, and to investigate the relationships among the tested parameters, especially the relationships between the count of aerobic mesophilic bacteria and physico-chemical parameters as well as bacterial indicators of the faecal contamination.

\section{EXPERIMENTAL}

\section{Study area}

Ćelije Reservoir (4323'22" N; $21^{\circ} 09^{\prime} 48^{\prime \prime}$ E; Fig. 1) is located on Rasina River, at $23 \mathrm{rd} \mathrm{km}$ on the road from Kruševac to Brus. The reservoir was named after the village where the river was dammed. It extends in the direction north-south. Going downstream, the first lake basin, located in the village of Zlatari, belongs to the municipality of Brus, and the remaining two basins, located in the village of Ćelije, belong to the municipality of Kruševac. Ćelije is a typical hilly-mountain reservoir with complex morphometry. It is elongated in shape, about $10 \mathrm{~km}$ long and consists of three basins: Zlatari, Vasići and Watercatching basin. Basins have successively increasing depth (Zlatari 6-10 m, Vasići 22-24 m, Water-catching basin about 42 $\mathrm{m} \max$ ), and thus a volume, so the last basin contains more than a half of the lake water.

\section{Sampling}

During one year, once a month, the sampling of the Ćelije Reservoir water was carried out in all three basins - Zlatari (two sampling sites - S1 and S2), Vasići (one sampling site - S3) and Water-catching basin (two sampling sites - S4 and S5; Fig. 1). Sampling was carried out at different depths in relation to the temperature distribution. During the circulation periods (January, February, March, November and December), the sampling was carried out at the following depths: $\mathrm{S} 1-0.5 \mathrm{~m}, 1 \mathrm{~m}, 2-4 \mathrm{~m} ; \mathrm{S} 2$ $0.5 \mathrm{~m}, 1 \mathrm{~m}, 3 \mathrm{~m}, 6 \mathrm{~m}, 12 \mathrm{~m}$; S3 - $0.5 \mathrm{~m}, 1 \mathrm{~m}, 3 \mathrm{~m}, 6 \mathrm{~m}, 13 \mathrm{~m}, 20$ m; S4 - 0.5 m, 1 m, 3 m, 6 m, 14 m, 22 m, 30 m; S5 - 0.5 m, 1 m, $3 \mathrm{~m}, 6 \mathrm{~m}, 14 \mathrm{~m}, 22 \mathrm{~m}, 35 \mathrm{~m}$. In the periods of stagnation (April, May, June, July, August, September and October), the sampling was carried out at the following depths: $\mathrm{S} 1$ - as in the previous period; $\mathrm{S} 2$ - $0.5 \mathrm{~m}, 1 \mathrm{~m}, 3 \mathrm{~m}, 5 \mathrm{~m}, 7 \mathrm{~m}$ (thermocline), $12 \mathrm{~m}$; S3 0.5 m, 1 m, 3 m, 5 m, 7 m, 13 m, 21 m; S4 - 0.5 m, 1 m, 3 m, 5 m, 7 m, 14 m, 22 m, 30 m; S5 - 0.5 m, 1 m, 3 m, 5 m, 7 m, 14 m, $22 \mathrm{~m}, 35 \mathrm{~m}$.

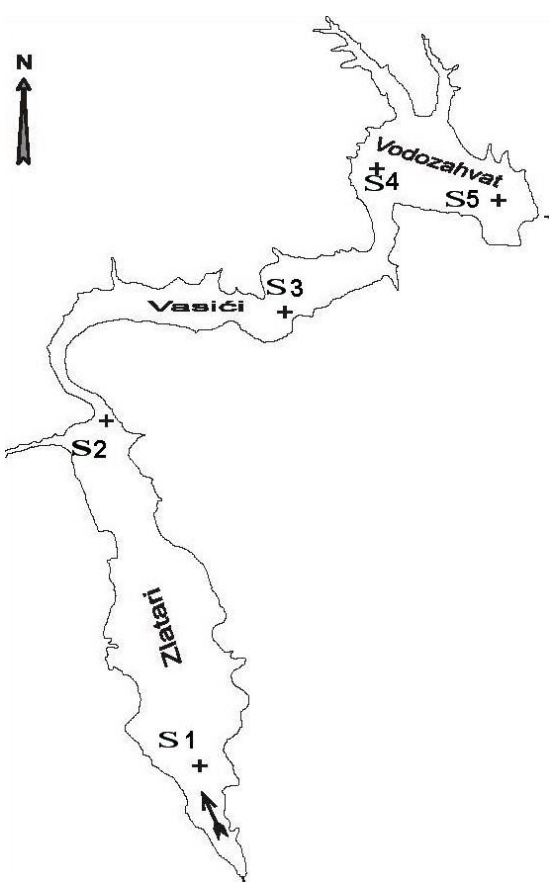

Figure 1. Ćelije Reservoir. S1, S2, S3, S4, S5 - sampling sites (Vodozahvat - Water-catching basin).

During the same year, the sampling of raw water was done at the site of the water intake, once a week.

The samples were taken with a Van Dorn bottle and immediately, in refrigerators, transported to the laboratories of the Drinking Water Plant in Majdevo, where they were processed.

\section{Materials and methods}

The water temperature was measured in situ by a digital thermometer. Other physico-chemical parameters $(\mathrm{pH}$, turbidity, conductivity, UV extinction, $\mathrm{KMnO}_{4}$ consumption, total phosphorus, orthophosphates, ammonium-, nitrite- and nitrate nitrogen) were determined by standard methods according to APHA (2012). The $\mathrm{pH}$ value was determined by the $\mathrm{pH}$-meter. Turbidity of water was determined nefelometrically according to the standard formazine polymer and expressed in nefelometric turbidity units (NTU). The conductivity was determined by the conductometer. UV-extinction was measured at $254 \mathrm{~nm}$ using Shimadzu UV-2401 PC ultraviolet/visible spectrophotometer. The $\mathrm{KMnO}_{4}$ consumption was determined by the oxidation of organic matter with potassium permanganate in the acidic environment $\left(\mathrm{H}_{2} \mathrm{SO}_{4}\right)$. The total phosphorus was determined spectrophotometrically, by measuring the color intensity of the complex that was built between orthophosphates, ammonium molybdate and antimonyl potassium tartarate, at $630 \mathrm{~nm}$. The concentrations of orthophosphates were determined by ammonium heptamolybdate technique. The ammonia concentrations were determined spectrophotometrically, with 
Nesler's reagent. The content of nitrite was determined by sulfanilic acid, spectrophotometrically. The content of nitrate was determined spectrophotometrically with hydrochloric acid.

The total count of aerobic mesophilic bacteria was determined by parallel inoculation of samples on a standard Plate Count Agar (PCA) and on the Reasoner's 2 Agar (R2A). PCA content is as follows: Tryptone $\left(5.0 \mathrm{~g} \cdot \mathrm{l}^{-1}\right)$, yeast extract $\left(2.5 \mathrm{~g} \cdot \mathrm{l}^{1}\right.$ $\left.{ }^{1}\right)$, glucose $\left(1.0 \mathrm{~g} \cdot \mathrm{l}^{-1}\right)$ and agar $\left(15.0 \mathrm{~g} \cdot \mathrm{l}^{-1}\right)$. R2A content is as follows: Meat peptone $\left(0.5 \mathrm{~g} \cdot \mathrm{l}^{-1}\right)$, yeast extract $\left(0.5 \mathrm{~g} \cdot \mathrm{l}^{-1}\right)$, casein hydrolyzate $\left(0.5 \mathrm{~g} \cdot \mathrm{l}^{-1}\right)$, glucose $\left(0.5 \mathrm{~g} \cdot \mathrm{l}^{-1}\right)$, starch $\left(0.5 \mathrm{~g} \cdot \mathrm{l}^{-1}\right)$, $\mathrm{K}_{2} \mathrm{HPO}_{4}\left(0.3 \mathrm{~g} \cdot \mathrm{l}^{-1}\right), \mathrm{MgSO}_{4} \times 7 \mathrm{H}_{2} \mathrm{O}\left(0.05 \mathrm{~g} \cdot \mathrm{l}^{-1}\right)$, Na-pyruvate $(0.3$ g. $\left.1^{-1}\right)$ and agar $\left(15.0 \mathrm{~g} \cdot \mathrm{l}^{-1}\right)$. The three dilutions: $10^{-1}, 10^{-2}$ and $10^{-3}$ of each sample were inoculated in the duplicate for both media. The inoculation was carried out using pour plate technique, and the inoculated plates were incubated at room temperature (20-22 $\left.{ }^{\circ} \mathrm{C}\right)$ for 7 days. The colonies were counted using the BZG-30 colonies counter (Windaus), through the lens with a magnification of $2 \mathrm{x}$. The count of bacteria was carried out on plates with the smallest dilution that could be read. The obtained number was calculated for $1 \mathrm{ml}$ of the sample, and presented as colony forming units per milliliter of water sample (cfu/ml).

Total bacterial count (direct count) - TBC, was determined by epifluorescence microscopy, after the dying of the water samples with acridine orange, as described by Ćirić (2009). Three morphotypes of bacteria were distinguished: rods, cocci and curved forms.

Bacterial biomass - BB estimations were made by examining photographs of random fields from selected samples, and then projecting the resulting images so that the minimum projected cell size was $\sim 1 \mathrm{~mm}$. Bacteria were sized by an eyepiece micrometer. Cell length and width were measured and converted to biovolume using the formula of Bratbak (1993). A single formula that worked well for rods and cocci was used to calculate the biovolume. Biovolume was converted to biomass

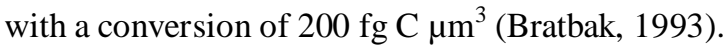

Total coliforms (TC) count was determined on Eijkman medium (Merck, Germany) at $37{ }^{\circ} \mathrm{C}$ after $48 \mathrm{~h}$ incubation, as most probable number per $100 \mathrm{ml}$ of water sample - MPN/100 $\mathrm{ml}$.

Faecal coliforms (FC) count was determined on Eijkman medium (Merck, Germany) at $44.5{ }^{\circ} \mathrm{C}$ after $24 \mathrm{~h}$ incubation, as MPN/100 ml.

Faecal streptococci (FS) count was determined on Slanetz and Bartley medium (Merck, Germany) with sodium azide and crystaline violet at $37^{\circ} \mathrm{C}$ after $72 \mathrm{~h}$ incubation, as MPN/100 ml.

Sulphite-reducing clostridia (SC) count was determined on Sulphate agar (Torlak, Serbia) at $37{ }^{\circ} \mathrm{C}$ after $48 \mathrm{~h}$ incubation, as CFU/100 ml.

\section{Statistical analyses}

Determination of the correlation coefficients among the investigated physico-chemical and microbiological parameters of water was carried out using statistical software STATISTICA v. 10, StatSoft, Inc.

\section{RESULTS}

Average, maximum and minimum values of physicochemical parameters in Ćelije Reservoir and the raw water are given in Table 1. The highest average temperature was recorded in summer $\left(16.5^{\circ} \mathrm{C}\right)$, and the lowest in winter $\left(5.9^{\circ} \mathrm{C}\right)$. Starting from the shallowest part of the reservoir (S1) to the deepest (S5), the temperature gradually decreased in all seasons, so that, on average, the water-catching basin was colder than the first basin (Zlatari I) by about $4{ }^{\circ} \mathrm{C}$. The fluctuation of the water temperature usually depends on the season, geographic location and sampling time (Venkatesharaju et al., 2010).

Previous studies have shown that Ćelije belongs to the mesotrophic lake ecosystems with the tendency of increasing of the trophic level (Marković et al., 1998). The sanitary protection zones of the reservoir as the water supply source for the town of Kruševac and its surroundings, although marked, are not respected. There is a strong negative anthropogenic impact on the reservoir because of the existence of the settlements on shores, agricultural land and erosion due to degraded forests in the lake basin.

Ćelije Reservoir is heavy modified water body formed on a type 3 water body and its quality is subject to the Rule book on the parameters of the ecological and chemical status of surface waters and the parameters of the chemical and quantitative status of groundwaters (Službeni glasnik RS, 74/11). On the basis of average annual values of physico-chemical parameters, the source water and raw water belong to the second class (according to the $\mathrm{pH}$ value, nitrate nitrogen, total and inorganic phosphorus) and the third class (according to the ammonium nitrogen). Based on the obtained results, it can be said that the reservoir has a moderate ecological potential. The ecological potential of a water body represents the degree to which the quality of the water body's aquatic ecosystem approaches the maximum it could achieve. In principle, there are five ecological potential classes: maximum, good, moderate, poor and bad (Water Framework Directive, 2008). However, in some seasons, some parameters exceeded the values prescribed for that class so, in those seasons water was of worse quality than average for one or even two classes. This is very important because the reservoir is used for drinking water supply in those seasons, too. Thus, orthophosphates in the winter and autumn periods exceeded the given values, especially in the water-catching basin, from where the water is taken for processing. According to this parameter, in these seasons the water was of poorer quality for one class, and it was classified in fourth class, which is not recommended for water supply. In the case of ammonium nitrogen, the average value in the autumn season exceeded the value of $1 \mathrm{mg} / \mathrm{l}$ (worse than the fifth class), so in this period the water can not be used for any purpose. The concentration of nitrate nitrogen remained 
stable throughout the year and none of the samples did not exceed the value prescribed for the second class. Total phosphorus also remained stable throughout the year and throughout the reservoir.

Table 1. Average, maximum and minimum values of physico-chemical parameters in Ćelije Reservoir and raw water.

\begin{tabular}{|c|c|c|c|c|c|c|c|}
\hline Parameter & S1 & S2 & S3 & S4 & S5 & Ćelije & Raw water \\
\hline Temperature $\left({ }^{\circ} \mathrm{C}\right)$ & $\begin{array}{c}16.0 \\
4.3-24.0\end{array}$ & $\begin{array}{c}16.1 \\
4.0-27.5\end{array}$ & $\begin{array}{c}14.4 \\
3.2-25.0\end{array}$ & $\begin{array}{c}13.5 \\
3.8-26.1\end{array}$ & $\begin{array}{c}13.4 \\
3.6-26.3\end{array}$ & $\begin{array}{c}14.3 \\
3.2-27.5\end{array}$ & $\begin{array}{c}10.2 \\
3.6-13.8\end{array}$ \\
\hline $\mathrm{pH}$ & $\begin{array}{c}8.35 \\
7.92-8.81\end{array}$ & $\begin{array}{c}8.27 \\
7.66-8.94\end{array}$ & $\begin{array}{c}8.14 \\
7.62-9.01\end{array}$ & $\begin{array}{c}8.06 \\
7.56-9.02\end{array}$ & $\begin{array}{c}8.07 \\
7.46-9.02\end{array}$ & $\begin{array}{c}8.14 \\
7.46-9.02\end{array}$ & $\begin{array}{c}7.78 \\
7.58-7.99\end{array}$ \\
\hline Turbidity (NTU) & $\begin{array}{c}11.70 \\
3.40-78.00\end{array}$ & $\begin{array}{c}9.20 \\
1.80-75.00\end{array}$ & $\begin{array}{c}5.47 \\
1.10-34.00\end{array}$ & $\begin{array}{c}3.94 \\
0.92-21.00\end{array}$ & $\begin{array}{c}4.13 \\
0.64-26.00\end{array}$ & $\begin{array}{c}5.89 \\
0.64-78.00\end{array}$ & $\begin{array}{c}6.83 \\
1.40-24.00\end{array}$ \\
\hline Conductivity $\left(\mu \mathrm{S} \cdot \mathrm{cm}^{-1}\right)$ & $\begin{array}{c}331.2 \\
294.6-361.2\end{array}$ & $\begin{array}{c}324.9 \\
284.4-360.5\end{array}$ & $\begin{array}{c}315.7 \\
257.3-357.7\end{array}$ & $\begin{array}{c}313.3 \\
251.3-352.1\end{array}$ & $\begin{array}{c}313.6 \\
255.3-365.4\end{array}$ & $\begin{array}{c}317.4 \\
251.3-365.4\end{array}$ & $\begin{array}{c}314.3 \\
283.8-347.2\end{array}$ \\
\hline UV extinction, $254 \mathrm{~nm}$ & $\begin{array}{c}10.8 \\
5.5-43.2\end{array}$ & $\begin{array}{c}9.5 \\
5.2-41.1\end{array}$ & $\begin{array}{c}10.7 \\
4.6-29.7\end{array}$ & $\begin{array}{c}9.7 \\
5.1-26.4\end{array}$ & $\begin{array}{c}10.0 \\
4.7-25.7\end{array}$ & $\begin{array}{c}10.1 \\
4.6-43.2\end{array}$ & $\begin{array}{c}11.7 \\
4.9-25.7\end{array}$ \\
\hline $\begin{array}{l}\mathrm{KMnO}_{4} \text { consumption } \\
\left(\mathrm{mg} \cdot \mathrm{l}^{-1}\right)\end{array}$ & \begin{tabular}{|c|}
13.92 \\
$10.55-19.90$
\end{tabular} & $\begin{array}{c}12.43 \\
9.23-20.81\end{array}$ & $\begin{array}{c}11.31 \\
7.90-15.91\end{array}$ & $\begin{array}{c}10.86 \\
7.58-14.22\end{array}$ & $\begin{array}{c}11.32 \\
7.90-22.12\end{array}$ & $\begin{array}{c}11.61 \\
7.58-22.12\end{array}$ & $\begin{array}{c}10.61 \\
7.58-12.72\end{array}$ \\
\hline Total P (mg. $\left.\mathrm{l}^{-1}\right)$ & $\begin{array}{c}0.080 \\
0.054-0.184 \\
\end{array}$ & $\begin{array}{c}0.069 \\
0.030-0.216 \\
\end{array}$ & $\begin{array}{c}0.054 \\
0.024-0.187\end{array}$ & $\begin{array}{c}0.051 \\
0.013-0.124\end{array}$ & $\begin{array}{c}0.065 \\
0.021-0.264\end{array}$ & $\begin{array}{c}0.061 \\
0.013-0.264\end{array}$ & $\begin{array}{c}0.074 \\
0.050-0.102 \\
\end{array}$ \\
\hline $\mathrm{PO}_{4}^{3-}\left(\mathrm{mg} \cdot \mathrm{l}^{-1}\right)$ & $\begin{array}{c}0.020 \\
0.000-0.074\end{array}$ & $\begin{array}{c}0.024 \\
0.000-0.089\end{array}$ & $\begin{array}{c}0.024 \\
0.000-0.093\end{array}$ & $\begin{array}{c}0.024 \\
0.000-0.088\end{array}$ & $\begin{array}{c}0.031 \\
0.000-0.202\end{array}$ & $\begin{array}{c}0.026 \\
0.000-0.202\end{array}$ & $\begin{array}{c}0.042 \\
0.025-0.064\end{array}$ \\
\hline $\mathrm{N}-\mathrm{NH}_{4}\left(\mathrm{mg} \cdot \mathrm{l}^{-1}\right)$ & $\begin{array}{c}0.107 \\
0.000-0.278\end{array}$ & $\begin{array}{c}0.197 \\
0.000-1.484\end{array}$ & $\begin{array}{c}0.162 \\
0.000-1.500\end{array}$ & $\begin{array}{c}0.139 \\
0.019-0.582 \\
\end{array}$ & $\begin{array}{c}0.342 \\
0.013-5.350 \\
\end{array}$ & $\begin{array}{c}0.204 \\
0.000-5.350\end{array}$ & $\begin{array}{c}0.177 \\
0.017-0.442 \\
\end{array}$ \\
\hline $\mathrm{N}-\mathrm{NO}_{2}\left(\mathrm{mg} \cdot \mathrm{l}^{-1}\right)$ & $\begin{array}{c}0.010 \\
0.000-0.027\end{array}$ & $\begin{array}{c}0.013 \\
0.000-0.055\end{array}$ & $\begin{array}{c}0.019 \\
0.000-0.128\end{array}$ & $\begin{array}{c}0.012 \\
0.000-0.308\end{array}$ & $\begin{array}{c}0.015 \\
0.000-0.212\end{array}$ & $\begin{array}{c}0.016 \\
0.000-0.308\end{array}$ & $\begin{array}{c}0.009 \\
0.000-0.025\end{array}$ \\
\hline $\mathrm{N}-\mathrm{NO}_{3}\left(\mathrm{mg} \cdot \mathrm{l}^{-1}\right)$ & $\begin{array}{c}0.481 \\
0.051-1.778 \\
\end{array}$ & $\begin{array}{c}0.409 \\
0.000-1.788 \\
\end{array}$ & $\begin{array}{c}0.547 \\
0.020-1.764\end{array}$ & $\begin{array}{c}0.642 \\
0.000-1.616\end{array}$ & $\begin{array}{c}0.586 \\
0.034-1.570 \\
\end{array}$ & $\begin{array}{c}0.540 \\
0.000-1.788 \\
\end{array}$ & $\begin{array}{c}0.916 \\
0.219-1.510\end{array}$ \\
\hline
\end{tabular}

The bacterial abundance $(\mathrm{cfu} / \mathrm{ml})$ in the source water ranged between 60 and $3.75 \times 10^{4}$ (on PCA) and between $2.25 \times 10^{2}$ and $1.79 \times 10^{5}$ (on R2A; Tab. 2). The earlier studies have shown that a significantly higher number of aerobic mesophilic bacteria has been detected on the low-nutrient $\mathrm{R} 2 \mathrm{~A}$ medium in relation to high-nutrient PCA medium, and after seven days of incubation, the number of bacteria on R2A was higher than PCA for $74 \%$ (Ćirić \& Petrović, 2009).

Table 2. Average, maximum and minimum values of bacterioplankton in Ćelije Reservoir and raw water (PCA-Plate Count Agar, R2A-Reasoner's 2 Agar, TBC-Total Bacterial Count, BB-Bacterial Biomass)

\begin{tabular}{|c|c|c|c|c|c|c|c|}
\hline $\begin{array}{c}\text { Bacterioplankton } \\
\text { properties }\end{array}$ & S1 & S2 & S3 & S4 & S5 & Ćelije & Raw water \\
\hline PCA $\left(\mathrm{cfu} \cdot \mathrm{ml}^{-1}\right)$ & $\begin{array}{l}5.61 \times 10^{3} \\
5.25 \times 10^{2}- \\
3.75 \times 10^{4}\end{array}$ & $\begin{array}{l}2.83 \times 10^{3} \\
2.30 \times 10^{2}- \\
3.14 \times 10^{4}\end{array}$ & $\begin{array}{c}1.72 \times 10^{3} \\
60-1.28 \times 10^{4}\end{array}$ & $\begin{array}{c}1.36 \times 10^{3} \\
70-1.73 \times 10^{4}\end{array}$ & $\begin{array}{l}1.66 \times 10^{3} \\
7.20 \times 10- \\
2.57 \times 10^{4}\end{array}$ & $\begin{array}{c}2.12 \times 10^{3} \\
60-3.75 \times 10^{4}\end{array}$ & $\begin{array}{c}2.03 \times 10^{3} \\
3.40 \times 10^{2}- \\
1.48 \times 10^{4}\end{array}$ \\
\hline $\mathrm{R} 2 \mathrm{~A}\left(\mathrm{cfu} \cdot \mathrm{ml}^{-1}\right)$ & $\begin{array}{l}2.12 \times 10^{4} \\
1.52 \times 10^{3}- \\
1.10 \times 10^{5}\end{array}$ & $\begin{array}{l}9.32 \times 10^{3} \\
3.80 \times 10^{2}- \\
6.23 \times 10^{4}\end{array}$ & $\begin{array}{l}7.75 \times 10^{3} \\
2.25 \times 10^{2}- \\
4.91 \times 10^{4}\end{array}$ & $\begin{array}{l}7.23 \times 10^{3} \\
3.00 \times 10^{2}- \\
1.79 \times 10^{5}\end{array}$ & $\begin{array}{l}4.73 \times 10^{3} \\
3.60 \times 10^{2}- \\
5.15 \times 10^{4}\end{array}$ & $\begin{array}{l}8.21 \times 10^{3} \\
2.25 \times 10^{2}- \\
1.79 \times 10^{5}\end{array}$ & $\begin{array}{l}5.06 \times 10^{3} \\
9.65 \times 10^{2}- \\
3.48 \times 10^{4}\end{array}$ \\
\hline $\mathrm{TBC}\left(\mathrm{no} \cdot \mathrm{ml}^{-1}\right)$ & $\begin{array}{l}1.79 \times 10^{7} \\
1.22 \times 10^{7}- \\
2.65 \times 10^{7}\end{array}$ & $\begin{array}{l}1.07 \times 10^{7} \\
7.50 \times 10^{6}- \\
1.56 \times 10^{7}\end{array}$ & $\begin{array}{c}3.46 \times 10^{6} \\
2.35 \cdot \times 10^{6}- \\
4.46 \times 10^{6}\end{array}$ & $\begin{array}{l}2.34 \times 10^{6} \\
1.33 \times 10^{6}- \\
4.44 \times 10^{6}\end{array}$ & $\begin{array}{l}1.49 \times 10^{6} \\
8.06 \times 10^{5}- \\
2.33 \times 10^{6}\end{array}$ & $\begin{array}{l}7.19 \times 10^{6} \\
1.33 \times 10^{6}- \\
2.65 \times 10^{7}\end{array}$ & $\begin{array}{l}1.17 \times 10^{6} \\
3.10 \times 10^{5}- \\
1.10 \times 10^{7}\end{array}$ \\
\hline $\mathrm{BB}\left(\mu \mathrm{gC} \cdot 1^{-1}\right)$ & $\begin{array}{c}546.85 \\
370.63-807.02 \\
\end{array}$ & $\begin{array}{c}327.70 \\
228.66-475.25\end{array}$ & $\begin{array}{c}105.57 \\
71.74-136.00\end{array}$ & $\begin{array}{c}71.40 \\
40.67-135.56\end{array}$ & $\begin{array}{c}45.52 \\
24.57-71.17 \\
\end{array}$ & $\begin{array}{c}219.41 \\
24.57-807.02 \\
\end{array}$ & $\begin{array}{c}41.01 \\
10.86-384.55\end{array}$ \\
\hline Rods in TBC (\%) & $\begin{array}{c}58.31 \\
38.71-71.08\end{array}$ & $\begin{array}{c}51.43 \\
35.37-67.50\end{array}$ & $\begin{array}{c}62.16 \\
50.00-83.33\end{array}$ & $\begin{array}{c}53.18 \\
40.00-75.00\end{array}$ & $\begin{array}{c}52.79 \\
41.38-60.98\end{array}$ & $\begin{array}{c}56.22 \\
35.37-83.33\end{array}$ & $\begin{array}{c}52.69 \\
29.39-74.11\end{array}$ \\
\hline Cocci in TBC (\%) & $\begin{array}{c}31.80 \\
21.57-45.48\end{array}$ & $\begin{array}{c}39.18 \\
30.00-46.60\end{array}$ & $\begin{array}{c}28.19 \\
16.67-33.33\end{array}$ & $\begin{array}{c}37.65 \\
25.00-50.00\end{array}$ & $\begin{array}{c}30.12 \\
21.95-40.00\end{array}$ & $\begin{array}{c}33.10 \\
16.67-50.00\end{array}$ & $\begin{array}{c}42.98 \\
21.23-67.62\end{array}$ \\
\hline $\begin{array}{l}\text { Curved bacteria in } \\
\text { TBC }(\%)\end{array}$ & $\begin{array}{c}9.89 \\
3.01-20.48\end{array}$ & $\begin{array}{c}9.39 \\
0.00-28.93\end{array}$ & $\begin{array}{c}9.65 \\
0.00-25.42\end{array}$ & $\begin{array}{c}9.17 \\
0.00-18.52\end{array}$ & $\begin{array}{c}17.09 \\
5.66-27.59\end{array}$ & $\begin{array}{c}10.68 \\
0.00-28.93\end{array}$ & $\begin{array}{c}4.33 \\
0.56-10.08\end{array}$ \\
\hline
\end{tabular}

Bacterial count on both media showed that, going downstream, from the shallowest to the deepest basin, water quality has improved, both due to the natural process of auto purification, and because of the better protection of the watercatching basin. The highest number of bacterioplankton was recorded in March, and the lowest in August. In the early spring, after snow melting, a large amount of water, carrying various materials from the lake shores was instilled into the reservoir. This led to the significant increase in the bacterial count. After that, the count of bacteria dropped. There were two small 
increases in count, in June and September, which were probably the results of the anthropogenic activity. According to Kohl (1975), the reservoir belongs to the second class of water (moderately contaminated water). According to the Rule book on the parameters of the ecological and chemical status of surface waters and the parameters of the chemical and quantitative status of groundwater (Službeni glasnik RS, 74/11), based on the average number of aerobic mesophilic bacteria, the reservoir belongs to the second class (when the cultivation was done on PCA medium) i.e. to the third class (when the cultivation was done on R2A medium). This means that the reservoir water can be used for water supply, which is contrary to the also valid Rule book of the hygienic safety of drinking water (Službeni list SRJ, 42/98). Under this Regulation, the water of open source used for water supply should not contain more than 300 aerobic mesophilic bacteria in $1 \mathrm{ml}$. All examined samples of the water of Ćelije Reservoir, including raw water, contained more bacteria than prescribed.

Based on the direct number of bacteria (Tab. 2), the source water was also classified into the class of moderately contaminated waters, while the raw water was classified even in the class of maximum clean waters (Ambrazene, 1976).

Table 3. Matrix of production moment correlation coefficient (r) among analyzed physico-chemical and bacteriological variables of Ćelije Reservoir (Temp.-Temperature, UV ext.-UV extinction, $\mathrm{KMnO}_{4}$ con.- $\mathrm{KMnO}_{4}$ consumption, Orthoph.-Orthophosphates, Cond.Conductivity, d.-days, TBC-Total Bacterial Count, BB-Bacterial Biomass)

\begin{tabular}{|c|c|c|c|c|c|c|c|c|c|c|c|c|c|c|c|c|c|c|}
\hline & $\underset{\stackrel{\Xi}{0}}{\stackrel{\dot{\Xi}}{\oplus}}$ & $\begin{array}{l}\dot{\vec{x}} \\
\vec{b}\end{array}$ & 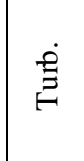 & $\stackrel{I}{2}$ & $\begin{array}{l}\dot{0} \\
0 \\
O^{+} \\
\sum_{i}\end{array}$ & 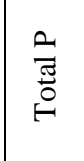 & $\begin{array}{l}\frac{\dot{0}}{2} \\
\frac{0}{0} \\
0\end{array}$ & $\begin{array}{l}Z_{1} \\
\text { 田 } \\
Z\end{array}$ & $\begin{array}{l}z_{1} \\
\delta^{\prime} \\
z\end{array}$ & $\begin{array}{l}z_{1} \\
0 \\
\delta^{\prime}\end{array}$ & ठ் & 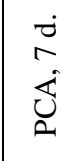 & $\begin{array}{l}\dot{r} \\
\underset{\mathbb{Z}}{\approx}\end{array}$ & U & $\stackrel{\varphi}{\varphi}$ & $\begin{array}{l}0 \\
0 \\
0 \\
\approx\end{array}$ & $\begin{array}{l}\delta^{\circ} \\
\bar{\delta} \\
\dot{0}\end{array}$ & 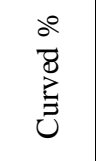 \\
\hline Temperature & 1 & -0.666 & -0.582 & 0.033 & 0.246 & -0.641 & -0.819 & -0.332 & -0.012 & -0.677 & -0.122 & -0.620 & -0.390 & -0.116 & -0.116 & -0.151 & 0.260 & -0.067 \\
\hline UV extinction & \begin{tabular}{|l|}
-0.666 \\
\end{tabular} & 1 & 0.954 & 0.070 & 0.187 & 0.761 & 0.660 & 0.338 & 0.001 & 0.792 & -0.206 & 0.921 & 0.768 & 0.224 & 0.224 & 0.097 & -0.314 & 0.196 \\
\hline Turbidity & -0.582 & 0.954 & 1 & 0.045 & 0.252 & 0.817 & 0.632 & 0.383 & 0.092 & 0.802 & -0.201 & 0.923 & 0.817 & 0.188 & 0.188 & 0.081 & -0.278 & 0.179 \\
\hline $\mathrm{pH}$ & 0.0333 & 0.070 & 0.045 & 1 & 0.174 & 0.284 & 0.110 & 0.170 & -0.183 & 0.032 & -0.418 & 0.055 & 0.051 & 0.247 & 0.247 & 0.138 & -0.018 & -0.166 \\
\hline $\mathrm{KMnO}_{4}$ consump. & 0.246 & 0.187 & 0.252 & 0.174 & 1 & 0.207 & -0.072 & -0.177 & -0.353 & -0.084 & -0.542 & 0.296 & 0.414 & 0.214 & 0.214 & 0.072 & -0.162 & 0.071 \\
\hline Total P & -0.641 & 0.761 & 0.817 & \begin{tabular}{|l|}
0.284 \\
\end{tabular} & 0.207 & 1 & 0.728 & 0.511 & -0.021 & 0.621 & -0.131 & 0.808 & 0.697 & 0.187 & 0.187 & 0.070 & -0.177 & 0.090 \\
\hline Orthophosphates & \begin{tabular}{|l|}
-0.819 \\
\end{tabular} & 0.660 & 0.632 & 0.110 & -0.072 & 0.728 & 1 & 0.597 & 0.097 & 0.611 & -0.154 & 0.617 & 0.443 & 0.022 & 0.022 & 0.201 & -0.401 & 0.146 \\
\hline $\mathrm{NH}_{4}-\mathrm{N}$ & \begin{tabular}{|l|}
-0.332 \\
\end{tabular} & 0.338 & 0.383 & 0.170 & -0.177 & 0.511 & 0.597 & 1 & 0.450 & 0.371 & -0.132 & 0.277 & 0.288 & -0.240 & -0.240 & 0.014 & -0.306 & 0.299 \\
\hline $\mathrm{NO}_{2}-\mathrm{N}$ & \begin{tabular}{|l|}
-0.012 \\
\end{tabular} & 0.001 & 0.092 & -0.183 & -0.353 & -0.021 & 0.097 & 0.450 & 1 & 0.312 & 0.196 & -0.017 & 0.161 & -0.149 & -0.149 & 0.088 & -0.069 & -0.047 \\
\hline $\mathrm{NO}_{3}-\mathrm{N}$ & \begin{tabular}{|l|}
-0.677 \\
\end{tabular} & 0.792 & 0.802 & 0.032 & -0.084 & 0.621 & 0.611 & 0.371 & 0.312 & \begin{tabular}{|l|}
1 \\
\end{tabular} & -0.113 & 0.748 & 0.651 & 0.145 & 0.145 & 0.245 & -0.332 & 0.015 \\
\hline Conductivity & -0.122 & -0.206 & -0.201 & -0.418 & -0.542 & -0.131 & -0.154 & -0.132 & 0.196 & -0.113 & 1 & -0.191 & -0.245 & -0.219 & -0.219 & -0.062 & 0.303 & -0.231 \\
\hline PCA, $7 \mathrm{~d}$. & \begin{tabular}{|l|}
-0.620 \\
\end{tabular} & 0.921 & 0.923 & \begin{tabular}{|l|}
0.055 \\
\end{tabular} & 0.296 & 0.808 & 0.617 & 0.277 & -0.017 & 0.748 & -0.191 & \begin{tabular}{|l|}
1 \\
\end{tabular} & 0.847 & 0.266 & 0.266 & 0.135 & -0.247 & 0.074 \\
\hline R2A, 7 d. & -0.390 & 0.768 & 0.817 & 0.051 & 0.414 & 0.697 & 0.443 & 0.288 & 0.161 & 0.651 & -0.245 & 0.847 & 1 & 0.391 & 0.391 & 0.169 & -0.258 & 0.041 \\
\hline TBC & -0.117 & 0.224 & 0.188 & 0.247 & 0.214 & 0.187 & 0.022 & -0.240 & -0.149 & 0.145 & -0.219 & 0.266 & 0.391 & 1 & 1.000 & -0.017 & 0.124 & -0.105 \\
\hline BB & \begin{tabular}{|l|}
-0.117 \\
\end{tabular} & 0.224 & 0.188 & \begin{tabular}{|l|}
0.247 \\
\end{tabular} & 0.214 & 0.187 & 0.022 & -0.240 & -0.149 & 0.145 & -0.219 & 0.266 & 0.391 & 1.000 & 1 & -0.017 & 0.124 & -0.105 \\
\hline Rods \% & -0.151 & 0.097 & 0.081 & 0.138 & 0.072 & 0.070 & 0.201 & 0.014 & 0.088 & 0.245 & -0.062 & 0.135 & 0.169 & -0.017 & -0.017 & 1 & -0.674 & -0.643 \\
\hline Cocci $\%$ & 0.260 & -0.314 & -0.278 & -0.018 & \begin{tabular}{|l|}
-0.162 \\
\end{tabular} & -0.177 & -0.401 & -0.306 & -0.069 & -0.332 & 0.303 & -0.247 & -0.258 & 0.124 & 0.124 & -0.674 & 1 & -0.132 \\
\hline Curved $\%$ & -0.067 & 0.196 & 0.179 & -0.166 & 0.071 & 0.090 & 0.146 & 0.299 & $\mid-0.047$ & 0.015 & -0.231 & 0.074 & 0.041 & -0.105 & -0.105 & -0.643 & -0.132 & 1 \\
\hline
\end{tabular}

Red marked correlations are significant at $\mathrm{p}<0.05$ level. $\mathrm{N}=55$.

Ghorbani et al. (2013) also showed a significantly high positive correlation coeficient $(r=0.758)$ between the count of heterotrophic bacteria and water turbidity and no relationships between the count of bacteria and $\mathrm{pH}$ value of water. According to Albaggar (2014), total phosphorus in water was one of the
The matrix of production moment correlation among analyzed physico-chemical and bacteriological variables is presented in Table 3. Aerobic mesophilic bacteria (on PCA and R2A) showed a significant positive correlation with UV extinction, turbidity, $\mathrm{KMnO}_{4}$ consumption, total phosphorus, orthophosphates, ammonium nitrogen and nitrate nitrogen. Also, these bacteria showed significant positive correlation with total bacterial count and bacterial biomass. This means that any of these bacteriological parameters will equally valid show changes in the bacteriological status of the aquatic ecosystem. A significant negative correlation of the number of bacteria with water temperature in all seasons suggests that bacteria are well adapted to the ambient temperature. Examining the source water, Donde (2012) also obtained the negative correlation between the bacterial count and water temperature. A significantly higher coefficient of correlation between aerobic mesophilic bacteria and turbidity, compared to the correlation coefficient between these bacteria and the $\mathrm{KMnO}_{4}$ consumption, shows that turbidity is a much better indicator of the organic load of water (Eregno, 2013). 
found a strong positive relationship between total bacterial abundance and total culturable bacteria, which is in accordance to this work.

The high negative correlation between the coccoid form of the bacteria and the elements of trophicity (turbidity, UV extinction, total and inorganic phosphorus, nitrates) confirms the findings that these forms of bacteria dominate in clean waters, since such a shape enables them a more efficient use of a small amount of available nutrients (Jochem, 2001). A limitingnutrient situation for bacteria is mostly accompanied with changes in cell morphology from rod-shaped cells to more coccoid forms (Velimirov et al., 2011). In this study, we could indeed find significant trends for the longitudinal development of the different morphotypes fitting to this postulation. For vibrioshaped cells, a significant reduction in cell volume was observed. The percentage of rods (total and free-living cells) significantly decreased towards the Delta, while the percentage of cocci significantly increased following concomitant changes of inorganic nutrients (nitrate and ammonium). This is also shown by the high negative correlation between the coccoid and the rod forms which is dominated in the waters rich in nutrients. The curved form of bacteria also showed a high negative correlation with the rods.

Among the physico-chemical parameters, water temperature was significantly negatively correlated with UV extinction, turbidity, phosphates, nitrates and bacterial load. This shows that the reservoir is a thermally very stable system.

To detect changes in the quality of water ecosystem, it was shown that, among physico-chemical parameters, turbidity was an excellent parameter. Turbidity showed a highly positive correlation with the pollution indicators (total phosphorus, orthophosphates, all forms of the mineral nitrogen and bacterial abundance). Among the bacteriological parameters, the best indicators of system changes are aerobic mesophilic bacteria.

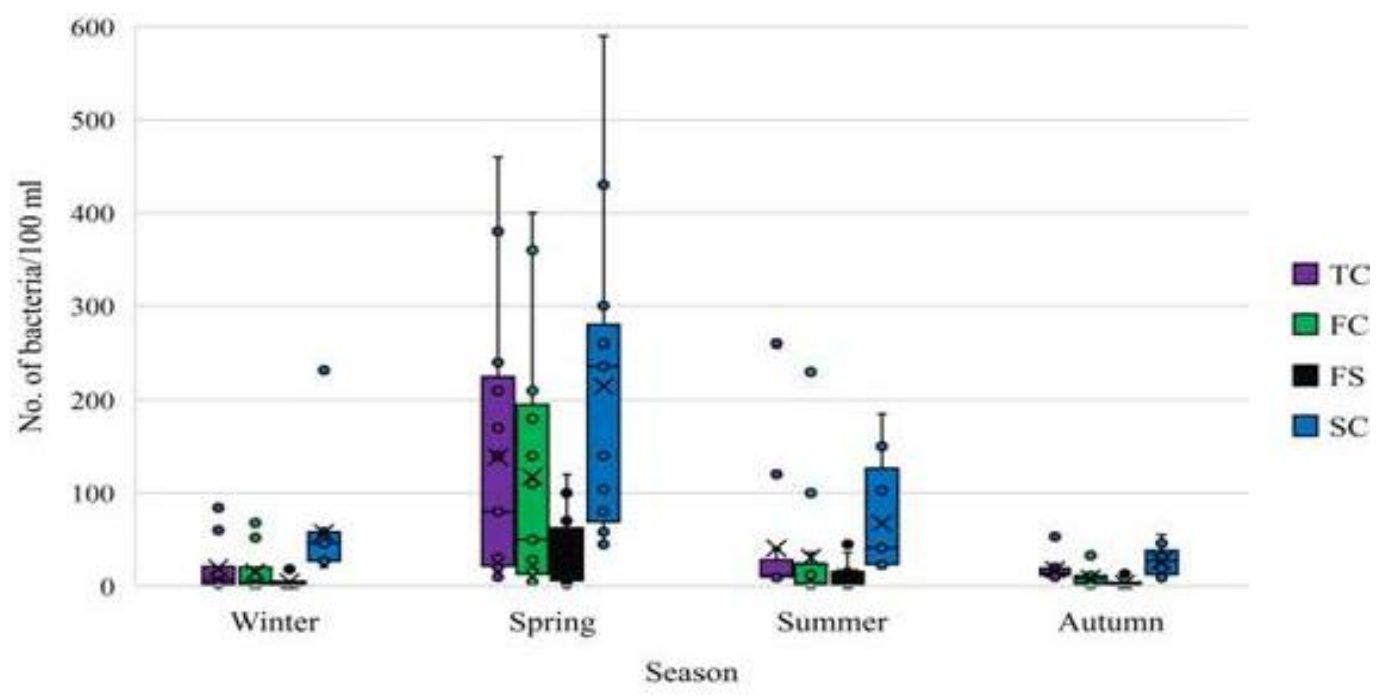

Figure 2. Seasonal variations of faecal indicator bacteria in raw water (TC-Total coliforms, FC-Faecal Coliforms, FS-Faecal Streptococci, SC-Sulphite-reducing Clostridia)

Average values of faecal indicator bacteria in raw water are showed in Fig. 2. All of the bacteriological indicators of faecal contamination had the highest values in $100 \mathrm{ml}$ of a water sample in the spring (TC - 149, FC - 126, FS - 39 and SC - 227), and the lowest in the autumn (TC - 17, FC - 8, FS - 2 and SC 27). According to Kavka (1994), over than $80 \%$ of the samples belong to slightly or less polluted waters. However, since it is an open source of drinking water, which should not contain faecal coliforms and faecal streptococci at all, and for the total coliforms and sulphite-reducing clostridia there is a maximum permissible values of $100 \mathrm{MPN} / 100 \mathrm{ml}$ and 10 bacteria/100 ml, respectively (Službeni list SRJ, 42/98), all of the raw water samples exceeded these values making this water unfit for the processing into drinking water.

Table 4. Matrix of production moment correlation coefficient ( $r$ ) between analyzed physico-chemical parameters and faecal indicator bacteria in raw water (TC-Total Coliforms, FC-Faecal Coliforms, FS-Faecal Streptococci, SC-Sulphite-reducing Clstridia)

\begin{tabular}{|c|c|c|c|c|c|c|c|c|c|c|c|}
\hline & Temp. & UV ext. & Turb. & $\mathrm{pH}$ & $\begin{array}{c}\mathrm{KMnO}_{4} \\
\text { consump. }\end{array}$ & Total $\mathrm{P}$ & $\mathrm{PO}_{4}{ }^{3-}$ & $\mathrm{NH}_{4}-\mathrm{N}$ & $\mathrm{NO}_{2}-\mathrm{N}^{-}$ & $\mathrm{NO}_{3}-\mathrm{N}$ & $\mathrm{Cond}$. \\
\hline TC & -0.344 & 0.461 & 0.902 & 0.369 & 0.326 & 0.334 & 0.168 & 0.321 & 0.155 & 0.421 & -0.350 \\
\hline FC & -0.343 & 0.457 & 0.913 & 0.379 & 0.316 & 0.339 & 0.171 & 0.340 & 0.155 & 0.409 & -0.340 \\
\hline FS & -0.390 & 0.614 & 0.909 & 0.403 & 0.382 & 0.465 & 0.271 & 0.416 & 0.220 & 0.443 & -0.276 \\
\hline SC & -0.528 & 0.705 & 0.842 & 0.485 & 0.373 & 0.530 & 0.368 & 0.416 & 0.170 & 0.590 & -0.248 \\
\hline
\end{tabular}



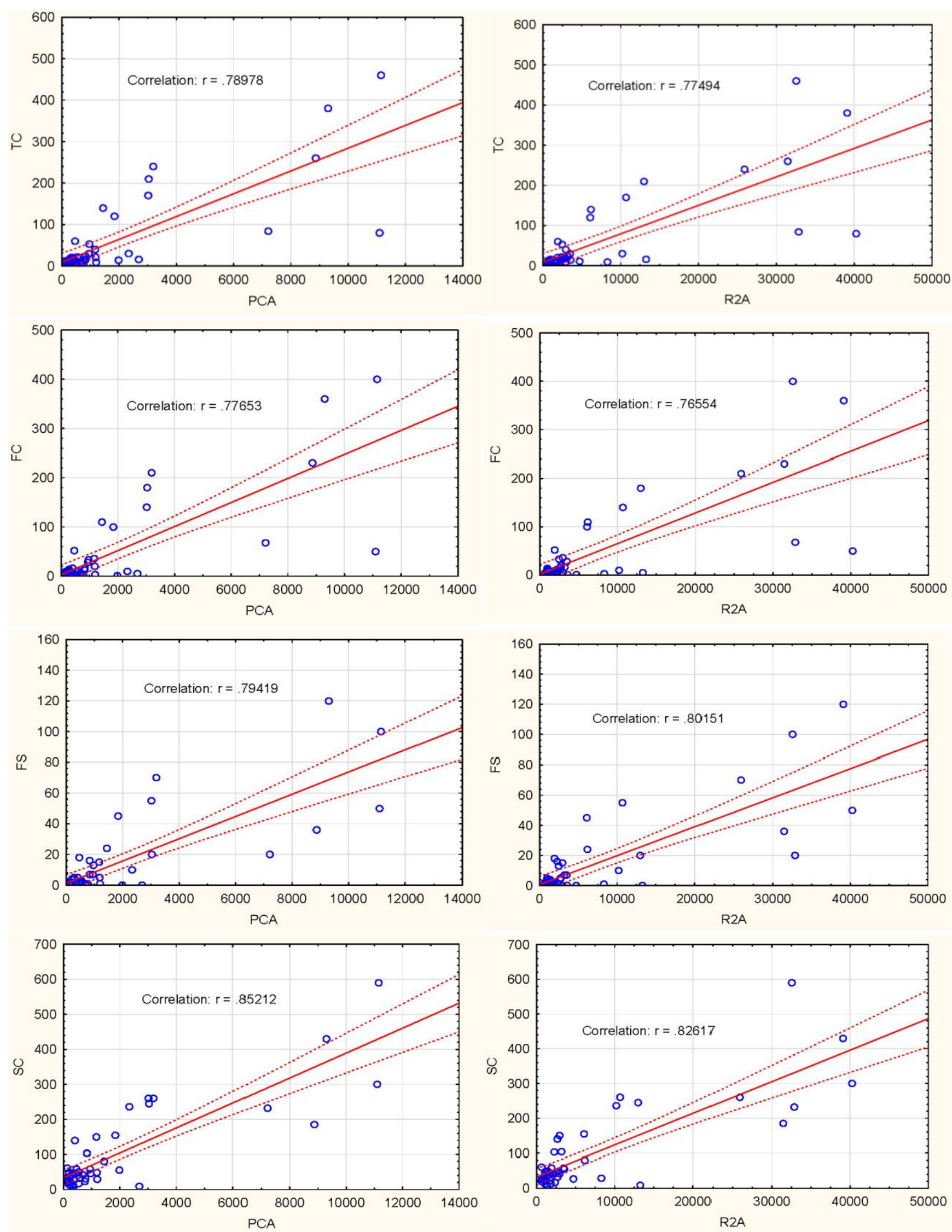

Figure 3. Relationships between aerobic mesophilic bacteria (PCA and R2A) and faecal indicator bacteria in raw water (TC-Total Coliforms, FC-Faecal Coliforms, FS-Faecal Streptococci, SC-Sulphite-reducing Clostridia) 
The matrix of production moment correlation between physico-chemical parameters and faecal indicator bacteria in raw water is presented in Table 4. All of the indicators of faecal contamination showed significant negative correlation with temperature, while the coliforms (total and faecal) showed the negative correlation with conductivity, too. The high positive correlation these bacteria showed with the UV extinction, turbidity, $\mathrm{pH}, \mathrm{KMnO}_{4}$ consumption, total phosphorus, ammonium and nitrate nitrogen, as well as the absence of the correlation with orthophosphates (except SC) and nitrites.

Relationships between faecal indicator bacteria and aerobic mesophilic bacteria in raw water are shown in Fig. 3. The correlation of faecal bacteria with aerobic mesophiles was determined from the results of cultivation, but not with direct (total) bacterial count, since faecal bacteria and aerobic mesophiles were determined by the same method - cultivation.

Although the differences in the number of bacteria obtained on PCA and R2A media were highly significant, both media showed a very high and very similar positive coefficient of correlation with all of the investigated indicators of the faecal pollution. This is in contrast to the findings of most authors, but there are also those who have obtained similar results. Donde (2012) showed a significantly high positive correlation between heterotrophic bacteria count and some faecal indicators (Escherichia coli, intestinal enterococci and Clostridium perfringens). In drinking water, Amanidaz et al. (2015) found that relationship between heterotrophic bacteria, coliforms and faecal streptococci was highly significant $(p<0.05)$, but they explained this by the presence of high concentrations of organic carbon, biofilms and nutrients, which are necessary for growth and survival of all microorganisms.

\section{CONCLUSION}

Based on the examined physico-chemical parameters, Ćelije Reservoir in some seasons did not correspond to the quality of the drinking water source. These seasons were winter and autumn, when there was a significant increase in the content of orthophosphates and ammonium nitrogen.

Based on the average number of aerobic mesophilic bacteria, the reservoir belonged to the second class (when the cultivation was done on PCA medium) or the third class (when the cultivation was done on R2A medium), but in each sample this number exceeded the upper limit prescribed by the Regulation of the hygienic correctness of drinking water. Based on these results, which are in accordance with the results of many authors, the change of the current regulative, in terms of the introduction of R2A medium for determining the count of aerobic mesophilic bacteria in waters instead of standard highnutrient medium, can be recommended.

Aerobic mesophilic bacteria (on both media) showed a significant positive correlations with UV extinction, turbidity, $\mathrm{KMnO}_{4}$, total $\mathrm{P}$, orthophosphates, ammonium- and nitrate nitrogen, TBC and BB. A significant negative correlation these bacteria showed with water temperature.

Among the faecal indicator bacteria, aerobic mesophilic bacteria showed high positive correlation with all tested faecal bacteria.

\section{REFERENCES}

Albaggar, A. K. A. 2014. Investigation of bacterial community composition and abundance in a lowland arable catchment.UK: University of East Anglia, School of Environmental Sciences. PhD Thesis.

Amanidaz, N., Zafarzadeh, A., \& Mahvi, A. H. 2015. The interaction between heterotrophic bacteria and coliform, fecal coliform, fecal streptococci bacteria in water supply networks. Iranian Journal of Public Health, 44(12), pp. 16851692.

Ambrazene, Z. P. 1976. Quantitative relationships between microorganisms and their use for evaluation of contamination in river waters. Zhurnal Obshtei Biologii, 37(3), pp. 416-425, In Russian.

-APHA. 2012. Standard methods for the examination of water and wastewater.American Public Health Association, American Water Works Association, Water Environment Federation. $22^{\text {nd }}$ Edition.

Bertram, J., Cotruovo, J., Exner, M., Fricker, C., \& Glasmacher, A. 2003. Heterotrophic plate counts and drinking-water safety: The significance of HPCs for water quality and human health. IWA Publishing. pp. 7-16.

Bezirtzoglou, E., Panagiou, A., Savvaidis, I., \& Maipa, V. 1997. Distribution of Clostridium perfringensin Polluted Lake Environments. Anaerobe, 3(2-3), pp. 169-172. doi:10.1006/anae.1997.0101

Bratbak, G. 1993. Microscope methods for measuring bacterial biovolume: epifluorescence microscopy, scanning electron microscopy, and transmission electron microscopy. In P.F. Kemp, B. F. Sherr, E. B. Sherr, \& J. J. Cole Eds., Handbook of Methods in Aquatic Microbial Ecology. Boca Raton, FL: Lewis Publishers. pp. 309-319.

Chróst, R. J., \& Siuda, W. 2006. Microbial production, utilization, and enzymatic degradation of organic matter in the upper trophogenic layer in the pelagial zone of lakes along a eutrophication gradient. Limnology and Oceanography, 51(1part2), pp. 749-762. doi:10.4319/lo.2006.51.1_part_2.0749

Ćirić, S. 2009. Aerobic mesophilic bacteria and low-nutrient R2A medium in monitoring of drinking water quality. Novi Sad: University of Novi Sad, Faculty of Science. PhD Dissertation, in Serbian.

Ćirić, S., \& Petrović, O. 2009. Comparison of cultural methods on bacterial recovery in source water for water supply. Fresenius Environmental Bulletin, 18(11a), pp. 2203-2209.

Donde, O. O. 2012. Bacteriological analysis of faecal pollution and solar radiation disinfection of domestic water sources within lake Naivasha Basin, Kenya. Kenya: Egerton University. Master of Science Thesis.

-Environment Agency of United Kingdom (EA UK). 2002. The microbiology of drinking water - Part I - Water quality and 
public health. http://www.environment-agency.gov.uk/ aboutus/default.aspx.

Freese, H. M., Karsten, U., \& Schumann, R. 2006. Bacterial Abundance, Activity, and Viability in the Eutrophic River Warnow, Northeast Germany. Microbial Ecology, 51(1), pp. 117-127. doi:10.1007/s00248-005-0091-5

Ghorbani, J., Moradianfard, S., Reisi, P., \& Gheysari, M. S. 2013. Survey of heterotrophic bacteria population changes in Kerman drinking water distribution system and GIS zoning. European Journal of Experimental Biology, 3(2), pp. 476483.

Jochem, F. J. 2001. Morphology and DNA content of bacterioplankton in the northern Gulf of Mexico: analysis by epifluorescence microscopy and flow cytometry. Aquatic Microbial Ecology, 25, pp. 179-194. doi:10.3354/ame025179

Kavka, G. G. 1994. Erfassung und Bewertung der bakteriologischen Beschaffenheit der Donau im Jahre 1993. Vergleich der Grenzprofile Deutschland-Österreich und Ústerreich-Slowakei. In 30. Arbeitstagung der IAD, Wissenschafftliche Kurzreferate.

Kohl, W. 1975. Uber die Bedeutung Bakteriologischer Untersuchungen fur die Beuerteilung von Fleissgewasser, Dargestellt am Beispiel der osterreich Donau. Archiv fur Hydrobiologie, 44(4), pp. 392-461.

Lemke, M. J., \& Leff, L. G. 2006. Culturability of Stream Bacteria Assessed at the Assemblage and Population Levels. Microbial Ecology, 51(3), pp. 365-374. doi:10.1007/s00248006-9026-z

Liguori, G., Cavallotti, I., Arnese, A., Amiranda, C., Anastasi, D., \& Angelillo, I. F. 2010. Microbiological quality of drinking water from dispensers in Italy. BMC Microbiology, 10(1), p. 19. doi:10.1186/1471-2180-10-19

Marković, G., Veljović, P., \& Simović, S. 1998. Biološki monitoring većih akumulacija u slivu reke Zapadne Morave. Kruševac: Konferencija "Vodni resursi sliva Velike Morave i njihovo korišćenje". pp. 356-360.

Muylaert, K., van der Gucht, K., Vloemans, N., de Meester, L., Gillis, M., \& Vyverman, W. 2002. Relationship between bacterial community composition and bottom-up versus topdown variables in four eutrophic shallow lakes. Applied and Environmental Microbiology, 68(10), pp. 4740-4750.

Paerl, H. W., Dyble, J., \& Moisander, P. H. 2003. Microbial indicators of aquatic ecosystem change: current applications to eutrophication studies. FEMS Microbiology Ecology, 46, pp. 233-246.

Poma, H. R., Gutiérrez, D. C., Garcé, B., Gonzo, E. E., \& Rajal, V. B. 2012. Towards a rational strategy for monitoring of microbiological quality of ambient waters. Science of Total Environment, 433, pp. 98-109.

Proctor, C. R., \& Hammes, F. 2015. Drinking water microbiology - from measurement to management. Current Opinion in Biotechnology, 33, pp. 87-94.

Sargaonkar, A., \& Deshpande, V. 2003. Development of an overall ondex of pollution for surface water based on a general classification scheme in Indian context. Environmental Monitoring and Assessment, 89(1), pp. 43-67.

Službeni glasnik RS 2011. Pravilnik o parametrima ekološkog i hemijskog statusa površinskih voda i parametrima hemijskog i kvantitativnog statusa podzemnih voda. Službeni glasnik RS, br. 74.

Službeni list SRJ 1998. Pravilnik o higijenskoj ispravnosti vode za piće. Službeni list SRJ, br. 42.

Szeląg-Wasielewska, E., \& Stachnik, W. 2010. Auto and heterotrophic picoplankton in a lowland river (Warta river, Poland). Oceanological and Hydrobiological Studies, 39(1), pp. 137-146.

Venkatesharaju, K., Ravikumar, P., Somashekar, R. K., \& Prakash, K. L. 2010. Physico-chemical and bacteriological investigation on the river Cauvery of kollegal strech in Karnataka. Kathmandu University Journal of Science, Engineering and Technology, 6(1), pp. 50-59.

-WHO. 2002. Reducing risks, promoting healthy life. World Health Report 2002.Geneva, Switzerland: World Health Organization. 